\title{
The Effect of Phosphorus and Transplanting Date on Growth, Yield and Yield Components of Onion (Allium Cepa L.) Under Irrigated Conditions at Adami Tulu Jedo Kombolcha Woreda, Oromia Region
}

\author{
Tilaye Anbes ${ }^{1} \quad$ Hussien Mohammed Beshir ${ }^{2}$ \\ 1.Alage ATVET College, Department of Plant Sciences, P.O.Box 77 Alage, Ethiopia \\ 2.Hawassa University, School of Plant and Horticultural Sciences, P.O.B.05, Hawassa, Ethiopia
}

\begin{abstract}
A field experiment was showed to decide the influence of transplanting date and phosphorus level on growth, yield and yield component of onion at Adami Tulu Jedo Kombolcha Woreda during 2017/18 season. The treatments comprised of three transplanting date (42, 49 and 56 days of transplanting date) and phosphorus levels $(0,23,46$, and $\left.69 \mathrm{~kg} \mathrm{P}_{2} \mathrm{O}_{5} \mathrm{ha}^{-1}\right)$. The experiment was laid out in RCBD with four replications. In this study, transplanting at 56 days of transplanting date fertilized with $69 \mathrm{~kg} \mathrm{P}_{2} \mathrm{O}_{5} \mathrm{ha}^{-1}$ recorded the highest total bulb yield and marketable bulb yield, but no significant difference was showed with that obtained at $46 \mathrm{~kg}_{2} \mathrm{O}_{5} \mathrm{ha}^{-1}$ with the same transplanting date. The economic analysis revealed that the highest net benefit with low cost of production was obtained in response to the application of $46 \mathrm{~kg} \mathrm{ha}^{-1}$ and the transplanting age of 56 days.
\end{abstract}

Keywords: bulb yield, Onion, economic analysis, phosphorus, transplanting date.

DOI: $10.7176 / \mathrm{JBAH} / 11-1-03$

Publication date: January $31^{\text {st }} 2021$

\section{Introduction}

Onion (Allium cepa L.) belongs to the genus Allium of the family Alliaceae (Hanelt, 1990). Onion is one of the most important monocotyledonous, cross-pollinated and cool season vegetable crops. Onions originated in Iran and Pakistan and were established as staple foods of Egypt and India around 1500 B.C. By the middle ages, it was introduced to Europe and then brought to North America by Spanish settlers. Onion is one of the most important crops and used both as a vegetable and spice (Barzegar et al., 2008). It can be eaten raw in salad, fried, boiled or roasted and also used in flavoring soups and canned food products (Gambo et al., 2008). It is highly demanded for its characteristics flavor and pungent taste as condiment, and for its medicinal value (Tyagi and Yadav, 2007).

Onion is a popular vegetable in Ethiopia and produced in many home gardens and commercially in different parts of the country. Its production is rapidly increasing both under rain-fed and irrigation conditions (Fekadu and Dandena, 2006). According to CSA (2010), during the preceding four years, the area coverage of onion in Ethiopia increased from 17,588 ha to $22,035.8$ ha with production changes from $169,316 \mathrm{t}$ to $236,922 \mathrm{t} / \mathrm{ha}$, which is about $25 \%$ and $40 \%$ increases, respectively. It is important cash crop for the farmers in Ethiopia; and hence the crop is produced in different parts of the country for local consumption and for export market.

Phosphorus deficiency is one of the largest constraints to crop production in many tropical soils, owing to low native content and high P fixation capacity of the soil (Fairhurst et al., 1999). Accordingly, P fertilization is usually recommended in these soils. Phosphorus is essential for root development and when the availability is limited, plant growth is usually reduced. In onions, P deficiencies reduce root and leaf growth, bulb size and yield and can also delay maturation (Brewster, 1994). Onions are generally established either by direct seeding or by bare root transplants. Compared to direct seeding, transplanted onions provide an immediate and complete stand.

While production of onion is expanding, information on optimum phosphorus fertilizer application rate and appropriate date of transplanting is revealing. Systematic study on fertilization to improve the growth and yield of bulb is deficient. Onion producers in the area use absolute recommendation of phosphorus fertilizer which was recommended at country level. As Ethiopia has a diversified agro-ecology and soil conditions, site specific fertilizer recommendation is needed to improve productivity and production of onion. On the other hand farmers transplant onion based on their own judgment on the age/size of seedlings which critically influence the productivity and quality of the bulb. In view of the prevailing problem, this study was proposed with the objective to determine the influence of phosphorus fertilizer and transplanting date on growth, bulb yield and yield components of onion.

\section{Materials and Methods}

Study Area

The study was conducted at Adami Tulu Jedo Kombolcha Woreda during the 2017/18 dry season under irrigation. The site is located $220 \mathrm{~km}$ south of Addis Ababa city and $34 \mathrm{~km}$ west of Bulbula town in the vicinity of Abidjata and Shalla lakes. It is situated between $7^{\circ} 65^{\prime} \mathrm{N}$ latitude and $38^{\circ} 56^{\prime}$ E longitudes and at an altitude of 1550 meters 
above sea level in the agro ecology of dry plateau of the southern part of the Ethiopian rift valley system. High amount of rainfall is received in the month of July and August. While the mean annual rainfall is $800 \mathrm{~mm}$, the annual mean minimum and maximum temperatures are $10{ }^{\circ} \mathrm{C}$ and $28{ }^{\circ} \mathrm{C}$, respectively (Agerie and Afework, 2013).

\section{Experimental Planting material}

The plant material for this study was Bombay Red variety of onion. The variety is widely accepted by farmers for its early maturity and higher bulb yield in the study area. It was released by Melkasa Agricultural Research Center (MARC) in 1980. It is well adapted to areas of 700-2000 meter above sea level (EARO, 2004). It is one of the most commonly and widely used improved variety in Central Rift Valley of Ethiopia and particularly at Adami Tulu Jedo Kombolcha Woreda.

\section{Treatments and Experimental Design}

The experiment was comprised of $4 \times 3$ factorial combinations involving levels of phosphorus and date of transplanting. Four levels of $\mathrm{P}\left(0,23,46\right.$, and $\left.69 \mathrm{~kg} \mathrm{P}_{2} \mathrm{O}_{5} \mathrm{ha}^{-1}\right)$ and three dates of transplanting $(42,49$ and 56 day of transplanting date) were laid out in randomized complete block design (RCBD) with four replications. Each treatment combination was assigned randomly to the experimental units within a block. Double row planting was done on ridges of about $20 \mathrm{~cm}$ height adopting recommended spacing of $40 \mathrm{~cm}$ between water furrows, $20 \mathrm{~cm}$ between rows on the ridge and $10 \mathrm{~cm}$ between plants within the row. There were 48 plots corresponding to the 12 treatment combinations with four replications. The unit plot size of the experiment was $2.4 \mathrm{~m} \times 2.3 \mathrm{~m}\left(5.52 \mathrm{~m}^{2}\right)$. The blocks were separated by a distance of $1.5 \mathrm{~m}$ whereas the space between each plot within a block was $1 \mathrm{~cm}$. In each plot, there were 12 rows, and in each row there were 20 plants. Totally, there were 240 plants per plot. The outer two rows at both sides of the plot and two plants at both ends of the rows were considered as border plants. The plants in the eight central rows were used as net plot area to determine yield per plot and other parameters.

\section{Agronomic Practices and Treatment Applications \\ Raising onion seedlings}

Seedlings of Bombay Red onion variety were raised on sunken beds with size of $1 \mathrm{~m} \times 5 \mathrm{~m}$. The seed of Bombay Red was obtained from Meki seed production P.L.C. After five sunken nursery beds were prepared, seeds were sown on December 15/2017. The soil was cultivated to a fine tilth before sowing the onion seed. The seed was drilled in well pulverized sunken bed in rows $15 \mathrm{~cm}$ apart and lightly covered with soil in the required seedling age. Mulching with grasses was done until seedlings emerged. The mulch was removed after seedlings fully emerged (2-4 cm from the soil). All important cultural practices such as application of fertilizer (Urea and NPS), watering, weed, diseases and insect pest control activities, respectively were undertaken based on the recommendations made for the onion crop.

\section{Management of experimental field}

Before transplanting seedlings, the experimental field was ploughed and leveled by Oxen; ridges and plots were made manually. Large clods were broken down in order to bring the land to a fine tilth, and then a total of 48 plots based on recommended size were prepared in which 12 plots were allocated in each of the four replications. Moreover, the required numbers of ridges and rows were marked in each plot. The seedlings were grown in the nursery with careful management and strict follow up until seedlings reached to the required stage as per the treatments. Seedlings were hardened before transplanting to the main field to enable them withstands the field conditions. The experiment was conducted under furrow irrigation method, which is the most commonly used irrigation system in the study area. A three to four days irrigation interval was maintained for the first four weeks. Thereafter, irrigation was applied at 7 days interval until 15 days remaining to harvest, when irrigation was stopped completely (EARO, 2004).

As per the recommendation made for the onion in the study area half $50 \mathrm{~kg} \mathrm{ha}^{-1}$ dose of $\mathrm{N}$ was applied uniformly to all plots during transplanting. The remaining half $50 \mathrm{~kg} \mathrm{ha}^{-1}$ dose of nitrogen rates was side-dressed 45 days after transplanting for all plots (EARO, 2004; SARC, 2008; Anisuzzaman et al., 2009). NPS was applied as a single application as per specified rates at the time of transplanting based on the treatments. Weeding was done with hand hoe and by hand-pulling whenever necessary throughout the experimental period to keep the crop free from weeds, for better soil aeration and to break the crust. For the control of disease (purple blotch) and insect pest (onion thrips) the fungicides, Mancozeb $80 \mathrm{WP}\left(3 \mathrm{~kg} \mathrm{ha}^{-1}\right)$ plus Ridomil $\left(3 \mathrm{~kg} \mathrm{ha}^{-1}\right)$ and the insecticide, Selecron $720 \mathrm{EC}\left(0.51 \mathrm{ha}^{-1}\right)$ were used, respectively. All other agronomic practices were applied uniformly for all the plots as per the recommendation made for the crop (EARO, 2004).

\section{Soil Sampling}

Before planting soil samples were taken randomly in a diagonal fashion from the experimental field at the depth 
of 0-30 cm for determination of physical and chemical properties of the soil. Nine soil samples were collected using an auger from the whole experimental field and combined to form a composite sample in a bucket. From this mixture, a sample weighing one $\mathrm{kg}$ was filled in to a plastic bag. The soil samples were also evaluated for soil texture, total nitrogen, cation exchange capacity (CEC), electric conductivity, organic carbon and available phosphorous. All the analyses were made at Hawassa soil and water analysis laboratory in Hawassa.

\section{Data Collection}

Maturity date was recorded on plot basis. Growth and yield components were recorded from ten sample plants randomly taken from eight central middle rows of each experimental plot. However, all plants in each net plot area were harvested to collect data for bulb yield parameters.

\section{Economic analysis}

Economic analysis was conducted to judge the economic feasibility of the treatments. It is a method of organizing experimental data and information about the costs and benefits of various alternative treatments. Partial budget, dominance and marginal analysis were used. The analysis was based on data collected from respective district office of trade and transport, cooperatives and from onion fields. At Adami Tulu Jedo Kombolcha Woreda, the cost of $100 \mathrm{~kg}$ phosphorus (TSP) was 1525 birr and onion price of 400 birr per $100 \mathrm{~kg}$ was used for the net benefit analysis. A partial budget is a way of calculating the total costs that vary and the net benefits of each treatment (CIMMYT, 1988).

\section{Data Analysis}

All the relevant data collected from the experimental plots were subjected to analysis of variances (ANOVA), which was computed using SAS computer software program (Version 9.2) and significant treatment means were compared using least significant difference (LSD) test at $\mathrm{P}<0.05$ probability level.

\section{Results and Discussion}

\section{Selected soil properties}

The experimental soil textural class of the experimental site was silty clay loam, having particle size distribution of $14 \%$ sand, $47 \%$ silt and $30 \%$ clay at the depth of $0-30 \mathrm{~cm}$. Its reaction is slightly alkaline $(\mathrm{pH}=7.82)$ which was appropriate for onion crop production according to Lemma and Shimeles (2003).

Table 1: Physico-chemical characteristics of the experimental soil.

\begin{tabular}{ll}
\hline Soil characteristics & Soil depth $\mathbf{( 0 - 3 0} \mathbf{~ c m}$ \\
\hline Total Nitrogen $(\%)$ & 0.18 \\
Organic carbon $(\%)$ & $2.10 \%$ \\
Available phosphorus $(\mathrm{mg} / \mathrm{kg})$ & 8.21 \\
Cation exchange capacity (cmol (+) kg-1 soil) & 31.8 \\
$\mathrm{pH}$ & 7.82 \\
Electric conductivity $(\mathrm{ds} / \mathrm{m})$ & 1.235 \\
Particle size distribution $(\%)$ & \\
Sand & $14 \%$ \\
Clay & $30 \%$ \\
Silt & $47 \%$ \\
Textural class & Silty clay loam \\
\hline
\end{tabular}

\section{Phonological Parameters \\ Maturity date}

Statistically, there was a significant difference for days to maturity for the factors $\mathrm{P}$ and transplanting date, but not significantly affected by the interaction effects of the treatments. It was also significantly late in plants from control plots by phosphorus, while plots received phosphorus at the rate of $69 \mathrm{~kg}_{2} \mathrm{O}_{5}$ ha $^{-1}$ matured earliest followed by $46 \mathrm{~kg} \mathrm{ha}^{-1} \mathrm{P}_{2} \mathrm{O}_{5}$ rate (Table 2). However, no significant difference was observed between control treatments and those received $23 \mathrm{~kg} \mathrm{P}_{2} \mathrm{O}_{5}$ ha $^{-1}$ plots. Generally, plants grown under higher phosphorus rates tended to be quick matured. The result indicates that the shortened time required by the plants to reach maturity at higher rates of phosphorus fertilizers might be recognized to the role of $\mathrm{P}$ in plants, that it is used in dry matter distribution which enables plant development, as a result, timely maturity of the plants. The significant function of phosphorus increases photosynthesis, reproduction, flowering, fruiting, including seed production and maturation of plants (Brady and Weil, 2002). The report is similar with Ahn (1993) who showed that P is concentrated in the fast growing parts of the plant; therefore, it accelerates the maturing period of crops.

The present result showed that, transplanting date at 42 and 49 days took relatively longer days for onion bulb to mature as compared to the 56 days of transplanting date. Onion plants with 56 days of transplanting reached 
maturity six and three days earlier than 42 and 49 days of transplanting date, respectively (Table 2). This result is in agreement with that of Kumbhkar et al. (2016) stated that onion seedlings that were transplanted at early stage were delayed to attain maturity. Early maturity of bulbs might be due to vigorous growth of plants because of stored food in late transplanting date which results in faster development and earlier maturity of bulb as compared to other early transplanting time (Bijarniya et al., 2015).

\section{Plant height}

Result from the analysis of variance showed that the main effects of transplanting date $(\mathrm{P}<0.01)$ and phosphorus $(\mathrm{P}<0.001)$ significantly influenced plant height of onion. But, the interaction of the two factors did not influence plant height. Increasing the rate of phosphorus fertilizer from nil up to $46 \mathrm{~kg} \mathrm{P}_{2} \mathrm{O}_{5} \mathrm{ha}^{-1}$ resulted in a significant increase in plant height. However, increasing the rate of phosphorus from $46 \mathrm{~kg} \mathrm{P}_{2} \mathrm{O}_{5} \mathrm{ha}^{-1}$ to $69 \mathrm{~kg} \mathrm{P}_{2} \mathrm{O}_{5} \mathrm{ha}^{-1}$ did not change the height of the onion plants. The tallest mean plant heights were recorded at $46 \mathrm{~kg}_{2} \mathrm{O}_{5}$ ha $^{-1}$, although the shortest plant height was obtained under the nil treatment. The mean height of onion plants grown at the rate of $46 \mathrm{~kg} \mathrm{P}_{2} \mathrm{O}_{5}$ ha $^{-1}$ overdone the mean height of plants grown at the rates of 23 and $0 \mathrm{~kg}_{2} \mathrm{O}_{5}$ ha ${ }^{-1}$ by about 7 and $13 \%$, respectively (Table 2). This might be attributed to the fact that phosphorus improves plant vigor and strength of the stem of the plant (Bahadur et al., 2002). The result of this study approves the findings of Ali et al. (2008), Muoneke et al. (2003), Aliyu et al. (2007) and Tibebu et al. (2014) who stated that different phosphorus levels resulted in significantly different plant heights where the tallest plants were observed at higher rates of applied phosphorus, while the shortest plants were from the control plots. The result also agreed with the findings of Lemma and Shimeles (2003) who reported that at $46 \mathrm{~kg} \mathrm{P}_{2} \mathrm{O}_{5}$ ha $^{-1}$ there was better vegetative growth which resulted in increased heights of onion plants.

There was a significant difference in plant height at maturity among the various days of transplanting date recorded (Table 2). Numerically the highest plant height was obtained from the plant when they were transplanted at 56 days of transplanting followed by the plants at 49 days of transplanting date; while the shortest was obtained under 42 days of transplanting date but statistically similar with 49 days of age. In general, the longer plant height at the oldest seedling might be due to more time of completion before transplanting stimulating height of seedlings as compared to the youngest seedling age which resulted in better establishment and vigorous growth of plant but shorter in height. This result is in agreement with that of Kanton et al. (2002), who found that significantly tallest plants of onion were recorded from the oldest seedling than the youngest one. Similarly, Bijarniya et al. (2015) reported that the more plant height at 56 days old seedling stage might be due to their greater stored food present in them as compared to the 42 old ones. This result is also in line with that of Sultan (2015) who found that the maximum plant height was recorded from 49 days old seedlings.

\section{Leaf length}

Leaf length of onion plants was significantly affected by the main effects of phosphorus and transplanting date treatments. But, no interaction effect of those treatments. This study indicated that, application of $69 \mathrm{~kg} \mathrm{P}_{2} \mathrm{O}_{5} \mathrm{ha}^{-}$ ${ }^{1}$ gave significantly longer leaf length than the lower doses $\left(0\right.$ and $\left.23 \mathrm{~kg} \mathrm{ha}^{-1}\right)$, whereas the $46 \mathrm{~kg} \mathrm{ha}^{-1} \mathrm{P}$ treatment did not significantly differ from $69 \mathrm{~kg} \mathrm{P}_{2} \mathrm{O}_{5}$ ha $^{-1}$ in leaf length (Table 2). The shortest leaf length was attained under the control treatments. Also significant difference was observed between the 23 and $46 \mathrm{~kg} \mathrm{ha}^{-1} \mathrm{P}$ rates. In general, leaf length tended to show an increasing trend as phosphorus rate increases. The leaf length response to phosphorus fertilizer rate is in agreement with Fageria et al. (2003) reported that higher rates of phosphorus resulted in longer leaves of onion. The positive effect of phosphorus on leaf length might be due to the fact that it contains an essential component of nucleic acids, phospholipids, and some amino acids and absorbed phosphorus helped a direct stimulation of cellular activity in roots and leaves (Jawar et al., 2016).

The longest leaf was perceived when seedlings are transplanted at 56 days of age, whereas numerically the shortest leaf length was obtained under 42 days of transplanting date (Table 2). The result is confirmed by Singh and Chaure (1999) who reported that longer leaves were noted at old seedling age as compared to treatments of the young ones. Similarly, Muhammad et al. (2017) and Sultan (2015) also described that the length of leaf was significantly influenced by the different transplanting date of onion. 
Table 2: Main effect of $\mathrm{P}$ levels and transplanting date on mean plant height, leaf length, number of leaves per plant, days to maturity, bulb diameter and bulb length at Adami Tulu Jedo Kombolcha Woreda.

\begin{tabular}{|c|c|c|c|c|c|c|}
\hline Treatments & $\begin{array}{l}\text { Days to } \\
\text { Maturity }\end{array}$ & $\begin{array}{l}\text { Plant } \\
\text { height } \\
\text { (cm) }\end{array}$ & $\begin{array}{l}\text { Leaf } \\
\text { length } \\
(\mathrm{cm})\end{array}$ & $\begin{array}{l}\text { Number } \\
\text { of leaves } \\
\text { per plant }\end{array}$ & $\begin{array}{l}\text { Bulb } \\
\text { diameter }(\mathrm{cm})\end{array}$ & $\begin{array}{l}\text { Bulb length } \\
\text { (cm) }\end{array}$ \\
\hline \multicolumn{7}{|l|}{$\mathrm{P}_{2} \mathrm{O}_{5}\left(\mathrm{~kg} \mathrm{ha}^{-1}\right)$} \\
\hline 0 & $103.12^{\mathrm{a}}$ & $51.58^{c}$ & $42.00^{c}$ & $9.33^{c}$ & $4.11^{b}$ & $4.21^{\mathrm{c}}$ \\
\hline 23 & $102.01^{\mathrm{a}}$ & $54.17^{\mathrm{b}}$ & $44.90^{\mathrm{b}}$ & $10.33^{b}$ & $4.33^{\mathrm{ab}}$ & $4.51^{b c}$ \\
\hline 46 & $100.46^{\mathrm{b}}$ & $58.35^{\mathrm{a}}$ & $48.87^{\mathrm{a}}$ & $11.95^{\mathrm{a}}$ & $4.58^{\mathrm{a}}$ & $4.85^{\mathrm{b}}$ \\
\hline 69 & $99.23^{c}$ & $57.00^{\mathrm{a}}$ & $47.57^{\mathrm{a}}$ & $11.96^{\mathrm{a}}$ & $4.59^{\mathrm{a}}$ & $5.45^{\mathrm{a}}$ \\
\hline LSD(0.05) & 1.32 & 2.56 & 2.22 & 0.96 & 0.32 & 0.47 \\
\hline Significance level & $* * *$ & $* * *$ & $* * *$ & $* * *$ & $* *$ & $* * *$ \\
\hline \multicolumn{7}{|l|}{$\begin{array}{l}\text { Transplanting } \\
\text { date(days) }\end{array}$} \\
\hline 42 & $104.06^{\mathrm{a}}$ & $53.36^{\mathrm{b}}$ & $44.24^{\mathrm{b}}$ & 12.79 & 5.92 & $4.56^{b}$ \\
\hline 49 & $101.02^{\mathrm{b}}$ & $55.37^{\mathrm{ab}}$ & $45.49^{b}$ & 12.53 & 5.43 & $4.62^{b}$ \\
\hline 56 & $98.75^{\mathrm{c}}$ & $57.40^{\mathrm{a}}$ & $47.78^{\mathrm{a}}$ & 12.98 & 5.94 & $4.78^{\mathrm{a}}$ \\
\hline LSD(0.05) & 1.07 & 2.031 & 1.92 & - & - & 0.30 \\
\hline Significance level & $* * *$ & $* *$ & $* *$ & NS & NS & $*$ \\
\hline CV $(\%)$ & 1.50 & 5.25 & 9.86 & 6.28 & 7.83 & 10.91 \\
\hline
\end{tabular}

Means followed by the same letters within a column are not significantly different at $(\mathrm{P}<0.05)$, LSD 0.05 .

\section{Number of leaves per plant}

Data on number of leaves per plant in table 2 clearly indicated that application of phosphorus fertilizer has a highly significant $(\mathrm{P}<0.001)$, but not significant different of transplanting date and its interaction. The result indicated that, effect of different rates of phosphorus on the number of leaves per plant increased with the increase in phosphorus level. The highest number of leaves was obtained from $69 \mathrm{~kg} \mathrm{P}_{2} \mathrm{O}_{5} \mathrm{ha}^{-1}$, whereas the lowest leaf number was obtained under the control treatment. Increasing the rate of phosphorus from nil to $46 \mathrm{~kg}_{2} \mathrm{O}_{5} \mathrm{ha}^{-1}$ significantly increased the number of leaves per plant of onion. But, the mean leaf number per plant did not show significant difference with further increase in phosphorus rate from 46 to $69 \mathrm{~kg} \mathrm{ha}^{-1}$. Thus, the mean leaf number per plant of onion treated with phosphorus at the rate of $46 \mathrm{~kg} \mathrm{ha}^{-1}$ exceeded the leaf number per plant of onion treated with nil and $46 \mathrm{~kg} \mathrm{P}_{2} \mathrm{O}_{5}$ ha $^{-1}$ by about 21 and $10 \%$, respectively (Table 2). This might be attributed to the role of $\mathrm{P}$ in plants, that it is used in dry matter distribution, which facilitates plant development.

The increase in the number of leaves as a result of the enhanced rates of phosphorus application may be attributed to the useful role of $\mathrm{P}$ for the process of cell division and meristematic growth. Similarly, Fatma et al., (2012) reported that the higher level of P fertilizer at $45 \mathrm{~kg} \mathrm{ha}^{-1}$ significantly increased plant height, number of green leaves per plant, bulb and neck dimensions and fresh and dry weights of whole plant and its different organs as compared with the lower level of $69 \mathrm{~kg} \mathrm{ha}^{-1}$

\section{Yield and Yield Components of Onion}

\section{Bulb diameter}

The results of the analysis of variance (Table 2) indicated that different levels of Phosphorus fertilizer significantly $(\mathrm{P}<0.01)$ influenced the bulb diameter of onion, however transplanting date and its interaction did not affect this parameter. Applications of phosphorus at 23,46 and $69 \mathrm{~kg} \mathrm{P}_{2} \mathrm{O}_{5}$ ha $^{-1}$ gave similarly larger bulb diameters compared to the plants without added phosphorus. Similarly, Jawar et al., (2016) stated that the increment in bulb diameter due to phosphorus application might be due to the fact that phosphorus improved the carbohydrate content of the plants and it extended root growth, which ultimately increased the blub size. Regarding the rates, Shaheen et al., (2007) reported that bulb diameter significantly increased with the increases of phosphorus fertilizer up to $46 \mathrm{~kg}$ $\mathrm{ha}^{-1}$.

\section{Bulb length}

Bulb length were significantly affected by phosphorus $(\mathrm{P}<0.001)$ and transplanting date $(\mathrm{P}<0.05)$, but their interaction was not significant (table 2). The result indicated that, in response to rising the rate of phosphorus from nil to the 23,46 and $69 \mathrm{~kg} \mathrm{P}_{2} \mathrm{O}_{5}$ ha $^{-1}$, bulb length increased significantly. The highest bulb length was observed from $138 \mathrm{~kg} \mathrm{P}_{2} \mathrm{O}_{5}$ ha $^{-1}$ followed by $92 \mathrm{~kg} \mathrm{P}_{2} \mathrm{O}_{5}$ ha $^{-1}$, while significantly smaller bulb length was obtained under the control treatments (Table 2). The significant increase in bulb length in response to the increment in the rate of phosphorus fertilizer may be linked to the increase in dry matter production and it's partitioning to the bulb. It was higher with the application of phosphorus and this might be due to the fact that the phosphorus improved the carbohydrate content of the plants and it extended root growth, which ultimately helped in the increased length of 
onion bulb (Khodadadi, 2012).

At 42 days of transplanting date, the bulb length was significantly reduced, but no significant difference was observed with 49 days of transplanting date. Compared to the 42 and 49 days of transplanting date treatments, 56 days of transplanting date produced 12 and $10 \%$ longer bulbs, respectively. The highest bulb length was recorded with transplanting of 56 days of transplanting date, while numerically the lowest bulb length was recorded in 42 days of transplanting date (Table 2). This indicated that the 56 days of transplanting date had maintained longer leaves and greater height which may have helped for more vegetative growth and bulb development and ultimately an increase in length of bulb. This result is similar with that of Singh and Chaure (1999) and Bahadur and Singh (2005) who observed that increase of bulb length at late transplanting as compared to treatments of the early transplanting date. Similarly, Sultana (2015) reported that length of bulb increased in 50 days old seedlings, which were strong and larger in size at transplanting stage.

\section{Average bulb weight}

Average bulb weight were significantly affected by phosphorus levels $(\mathrm{P}<0.001)$ and transplanting date $(\mathrm{P}<0.01)$, but not by their interaction (Table 3). The result revealed that, the rate of phosphorus was increased from 0 to 23 and $46 \mathrm{~kg} \mathrm{P}_{2} \mathrm{O}_{5}$ ha $^{-1}$, there were significant increments in average bulb weight. When the rate of fertilizer was increased from $46 \mathrm{~kg} \mathrm{P}_{2} \mathrm{O}_{5}$ ha $^{-1}$ to $69 \mathrm{~kg} \mathrm{P}_{2} \mathrm{O}_{5} \mathrm{ha}^{-1}$, the average bulb weight did not change significantly. Thus, the heaviest bulbs were produced already at $46 \mathrm{~kg} \mathrm{P}_{2} \mathrm{O}_{5} \mathrm{ha}^{-1}$. The mean bulb weight of onion plants grown at the rate of $46 \mathrm{~kg} \mathrm{P}_{2} \mathrm{O}_{5} \mathrm{ha}^{-1}$ exceeded the average bulb weight of onion plants grown at the rates of 23 and $0 \mathrm{~kg} \mathrm{P}_{2} \mathrm{O}_{5} \mathrm{ha}^{-1}$ by about 11 and 33\%, respectively (Table 3). The significant increase in average bulb weight in response to the increased phosphorus level might be attributed to the role phosphorus played in improving the carbohydrate content of the plants and extending root growth, which increased the diameter and length of blubs and ultimately blub size (Jawar et al., 2016). This finding is also confirmed with that of Lemma and Shimeles (2003) who reported that at $46 \mathrm{~kg} \mathrm{P}_{2} \mathrm{O}_{5}$ ha $^{-1}$, there was better vegetative growth and the average bulb weight was $49 \mathrm{~g} / \mathrm{bulb}$ at Melkassa. At 42 days of transplanting date, the average bulb weight was significantly reduced, but no significant difference was observed with 49 days of transplanting date (Table 3). Compared to the 42 and 49 days of transplanting date treatments, 56 days of transplanting date produced 6 and 9\% larger bulbs, respectively. The highest average bulb weight was recorded from plots that were transplanted at 56 days of transplanting date, while the least average bulb weight was obtained when seedlings were transplanted at 42 days of transplanting date. It was possible that old seedling age took less time to recover from the transplanting shock in order to get established in the field (Latif, 2006; Latif et al, 2010). The result is confirmed by observations of Singh and Chaure (1999), Vachhani and Patel (1988) who stated that increased fresh bulb weight was obtained at old seedling age as compared to treatments of the young ones.

\section{Total biomass yield}

The analysis of variance revealed that the main effect of phosphorus fertilizer application significantly $(\mathrm{P}<0.05)$ influenced the total biomass yield of onion. But, transplanting date and its interaction with phosphorus were significant. Increasing the levels of phosphorus from 0 to $23 \mathrm{~kg} \mathrm{P}_{2} \mathrm{O}_{5}$ ha $^{-1}$ significantly increased the total biomass yield (Table 3). However, further application beyond $23 \mathrm{~kg} \mathrm{P}_{2} \mathrm{O}_{5}$ ha $^{-1}$ did not significantly increase the biomass yield. The total biomass yield of onion plants grown at a rate of $23 \mathrm{~kg} \mathrm{P}_{2} \mathrm{O}_{5}$ ha $^{-1}$ exceeded the total biomass yield of onion plants grown at rates of $0 \mathrm{~kg} \mathrm{P}_{2} \mathrm{O}_{5} \mathrm{ha}^{-1}$ by about $12 \%$. The highest total biomass yield was attained from the highest phosphorus rate $\left(69 \mathrm{~kg} \mathrm{ha}^{-1}\right)$ although not significantly different from those obtained at 23 and $46 \mathrm{~kg}$ $\mathrm{P}_{2} \mathrm{O}_{5} \mathrm{ha}^{-1}$, whereas the lowest total biomass yield was obtained under the control treatment. This result is similar with that of Shaheen et al. (2007) who reported that application of phosphorus had a major effect on the productivity of onion plant, hence increased total biomass yield. This result is in disagreement with that of Abdissa (2008) who reported that phosphorus has shown non-significant effect on total dry biomass yield of onion; thus, absence of response to phosphorus in the previous study might be due to sufficient amount of available $\mathrm{P}$ which was found in the soil of the experimental site.

\section{Unmarketable bulb yield}

The analysis of variance indicated that phosphorus application rate had significant $(\mathrm{P}<0.01)$ effect on unmarketable bulb yield of onion. However, neither the main effect of transplanting date nor its interaction with phosphorus affected unmarketable bulb yield. The result revealed that increasing the rates of application of phosphorus decreased the unmarketable bulb yield per hectare. Among all phosphorus rates the highest unmarketable bulb yield was recorded in the unfertilized plots, while the lowest was recorded at $69 \mathrm{~kg} \mathrm{ha}^{-1}$ phosphorus rate though this was statistically at par with $46 \mathrm{~kg} \mathrm{ha}^{-1}$ (Table 3 ). High unmarketable yield observed in low rates of phosphorus application have been associated with early bulb formation, severe stunting, and fewer large sized bulbs than those under high phosphorus rates. This result is disagreement with that of Tibebu et al. (2014) who reported that phosphorus had no significant effect on unmarketable yield of onion that might be due to adequate amount of 
available $\mathrm{P}$ which was found in the soil of the experimental site.

Table 3: Main effects of Phosphorus levels and transplanting date on average bulb weight, total biomass yield and unmarketable bulb yield of onion grown at Adami Tulu Jedo Kombolcha Woreda.

\begin{tabular}{|c|c|c|c|}
\hline Treatment & $\begin{array}{l}\text { Average } \\
\text { bulb } \\
\text { weight (g) }\end{array}$ & Total biomass yield $\left(\mathrm{t} \mathrm{ha}^{-1}\right)$ & $\begin{array}{l}\text { unmarketable } \\
\text { bulb } \\
\text { yield }\left(\mathrm{t} \mathrm{ha}^{-1}\right)\end{array}$ \\
\hline \multicolumn{4}{|l|}{$\mathrm{P}_{2} \mathrm{O}_{5}\left(\mathrm{~kg} \mathrm{ha}^{-1}\right)$} \\
\hline 0 & $66.84^{\mathrm{c}}$ & $43.69^{b}$ & $2.66^{\mathrm{a}}$ \\
\hline 46 & $80.42^{\mathrm{b}}$ & $49.05^{\mathrm{ab}}$ & $2.08^{\mathrm{ab}}$ \\
\hline 92 & $88.89^{\mathrm{a}}$ & $52.61^{\mathrm{a}}$ & $1.80^{\mathrm{bc}}$ \\
\hline 138 & $92.83^{\mathrm{a}}$ & $52.86^{\mathrm{a}}$ & $1.45^{\mathrm{c}}$ \\
\hline LSD(0.05) & 4.18 & 7.21 & 0.57 \\
\hline Significance level & $* * *$ & $*$ & $* *$ \\
\hline \multicolumn{4}{|l|}{ Transplanting date } \\
\hline 42 & $81.28^{b}$ & 47.32 & 1.88 \\
\hline 49 & $79.19^{b}$ & 48.69 & 2.06 \\
\hline 56 & $86.27^{\mathrm{a}}$ & 52.64 & 2.02 \\
\hline LSD(0.05) & 3.62 & - & - \\
\hline Significance level & $* *$ & NS & NS \\
\hline CV $(\%)$ & 6.13 & $\mathbf{1 7 . 5 1}$ & 33.75 \\
\hline
\end{tabular}

Means followed by the same letters within a column are not significantly different at $(\mathrm{P}<0.05)$

Total bulb yield

The main effect of phosphorus as well as that of transplanting date significantly $(\mathrm{P}<0.001)$ influenced the total bulb yield of onion. Additionally, the interaction effect of transplanting date and phosphorus application rate significantly $(\mathrm{P}<0.05)$ influenced the total bulb yield of the onion. Total bulb yield was significantly improved at $46 \mathrm{~kg} \mathrm{ha}^{-1} \mathrm{P}_{2} \mathrm{O}_{5}$ rate, At 42 days of transplanting date. Further increasing phosphorus up to $69 \mathrm{~kg} \mathrm{ha}^{-1}$ showed a decline in the total bulb yield by $29 \%$, however, no significant difference was showed among the two phosphorus rates except those unfertilized plots and $46 \mathrm{~kg} \mathrm{P}_{2} \mathrm{O}_{5}$ ha $^{-1}$, which were at par.

Under 49 days of transplanting date, the highest and lowest total bulb yields were recorded at $46 \mathrm{~kg} \mathrm{ha}^{-1}$ phosphorus and control treatments, respectively. However, no significant difference was recorded among 23 and $69 \mathrm{~kg} \mathrm{P}_{2} \mathrm{O}_{5} \mathrm{ha}^{-1}$ treatments. In the 56 days of transplanting date, $\mathrm{P}$ application rate at $46 \mathrm{~kg} \mathrm{ha}^{-1}$ and $69 \mathrm{~kg} \mathrm{ha}^{-1}$ improved total bulb yield by about 36 and 42\%, respectively compared to that of control treatment. However, the two phosphorus rate (46 and $69 \mathrm{~kg} \mathrm{ha}^{-1}$ ) had no significant difference at the same transplanting date of 56 days (figure 1). Generally, increased application rate of phosphorus produced higher total bulb yields with optimum seedling age ( 56 days transplanting date). The high total bulb yield produced due to phosphorus application and old seedling age might be because of increase in photosynthetic area of the plant (plant height and number of leaves) which in turn increased the amount of assimilate that could be partitioned to the storage organs (increased bulb diameter and average bulb weight). This may lead to improved carbohydrate content of the plants and extended root growth, which consequently increased the total bulb yield. In harmony to this result, Verma et al. (1971) reported that transplanted onion at 56 days old gave the highest yield of bulb. Similarly, Maurya et al. (1997) found that 60 days old seedlings gave the highest bulb yield of onion followed by those planted at 50 days. 


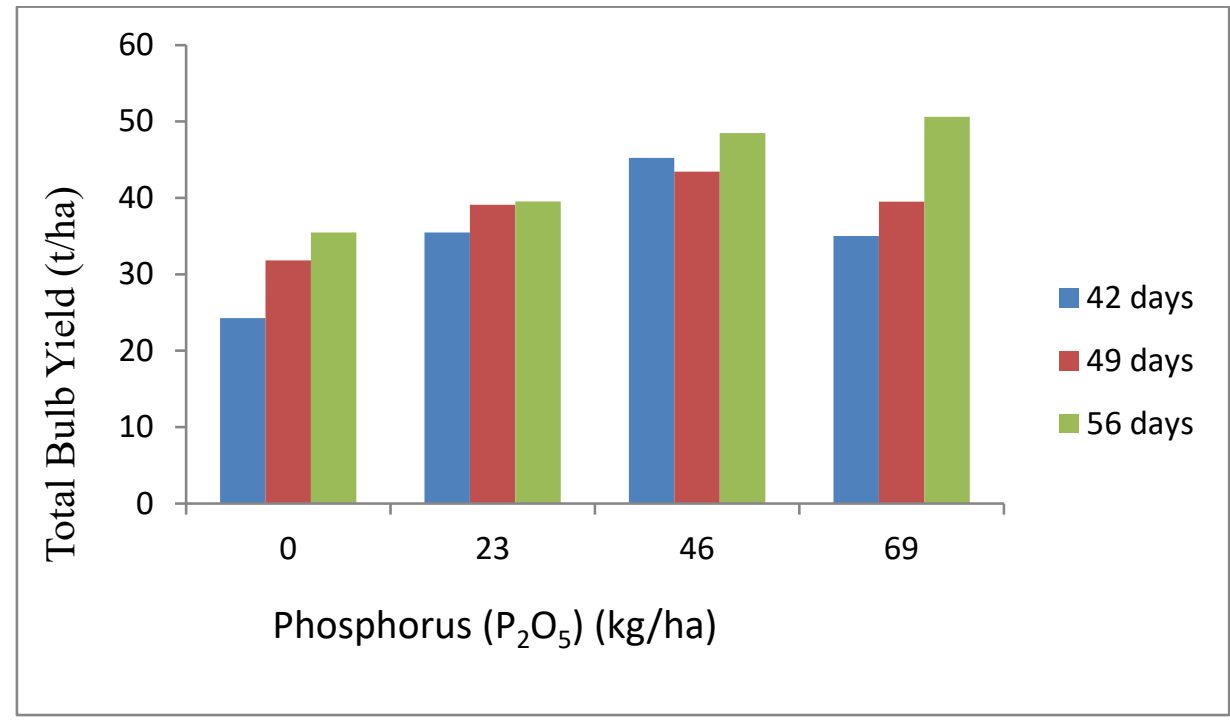

$\operatorname{LSD}(0.05)=4.43$, Significance level $=*$ and CV $(\%)=9.66$

Figure 1: Interaction effects of phosphorus levels and transplanting date on total bulb yield ( $\left.\mathrm{t} \mathrm{ha}^{-1}\right)$ of onion grown at Adami Tulu Jedo Kombolcha Woreda.

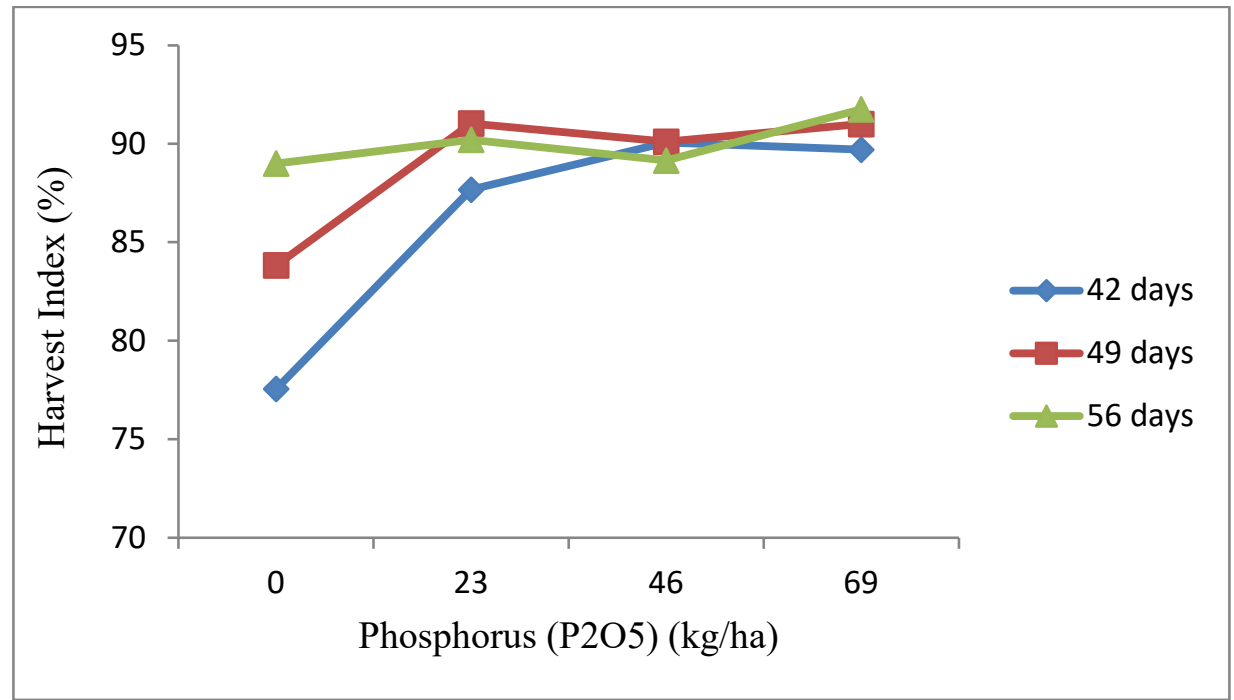

$\operatorname{LSD}(0.05)=3.00$, Significance level $=*$ and CV $(\%)=3.5$

Figure 2: Interaction effects of phosphorus levels and transplanting date on harvest index (\%) of onion grown at Adami Tulu Jedo Kombolcha Woreda.

\section{Harvest index}

The analysis of variance showed that harvest index was significantly $(\mathrm{P}<0.05)$ affected by the interaction effect of transplanting date and phosphorus level. Moreover, harvest index was significantly influenced by the main effects of transplanting date $(\mathrm{P}<0.01)$ and phosphorus application $(\mathrm{P}<0.001)$.

Generally, increased rate of phosphorus produced higher harvest index with increased transplanting date (figure 2). The highest harvest index was noted under the 56 days of transplanting date combined with application of $69 \mathrm{~kg} \mathrm{P}_{2} \mathrm{O}_{5} \mathrm{ha}^{-1}$, while the lowest value was obtained from transplanting of 42 days of transplanting date with the control treatment. At 42 day transplanting date, harvest index was significantly improved at $46 \mathrm{P}_{2} \mathrm{O}_{5} \mathrm{~kg} \mathrm{ha}^{-1}$ rate, further increasing of phosphorus up to $69 \mathrm{~kg} \mathrm{ha}^{-1}$ at this transplanting date showed a decline in the harvest index. However, statically no significant difference was indicated among the two phosphorus rate except those controlled plots and $23 \mathrm{~kg} \mathrm{ha}^{-1}$ which were at par. Under 49 day transplanting date, the highest and lowest harvest indices were attained at $23 \mathrm{~kg} \mathrm{ha}^{-1}$ phosphorus and control plots, respectively. However, no significant difference was recorded among 23, 46 and $69 \mathrm{~kg} \mathrm{P}_{2} \mathrm{O}_{5} \mathrm{ha}^{-1} \mathrm{P}$ rates. In the 56 days of transplanting date no significant difference was recorded among 0, 23, 46 and $69 \mathrm{~kg} \mathrm{P}_{2} \mathrm{O}_{5} \mathrm{ha}^{-1}$ treatments. Over all, differences among the three transplanting date levels become progressively narrower with increasing levels of $\mathrm{P}$ application. The high harvest index 
produced due to $\mathrm{P}$ application and higher transplanting date might be because of increased photosynthetic area of the plant (height of plants and number of leaves) which increased the amount of assimilate that could be partitioned to the storage organs (increased bulb length and average bulb weight) which consequently increased the harvest index.

\section{Marketable bulb yield}

Marketable bulb yield of onion was significantly affected $(\mathrm{P}<0.001)$ by the transplanting date and phosphorus rate. Similarly, significant interaction effect of transplanting date and phosphorus was observed on the marketable bulb yield of onion $(\mathrm{P}<0.05)$.

Under 42 days of seedling age, marketable bulb yield increased by about $100 \%$ at $46 \mathrm{~kg} \mathrm{ha}^{-1}$ phosphorus compared to lowest yield recorded from untreated plots (figure 3). Further increase of phosphorus to $69 \mathrm{~kg} \mathrm{ha}^{-1}$ did not significantly show variation, rather it showed a drop by about $30 \%$ and leveled off with yields from control plots and those fertilized at $23 \mathrm{~kg} \mathrm{ha}^{-1}$ phosphorus. At 56 days of transplanting date, the highest marketable bulb yield was produced at $46 \mathrm{~kg} \mathrm{ha}^{-1} \mathrm{P}$ rate while the lowest marketable bulb yield was obtained from control treatments. Significant differences were recorded among yields at 23, 46 and $69 \mathrm{~kg} \mathrm{ha}^{-1} \mathrm{P}$ rate under the 49 days age. At 56 days of transplanting date, the control plot had notably reduced yield of marketable bulb as compared to the three phosphorus levels. The highest marketable bulb yield was recorded at 56 days of transplanting date combined with $69 \mathrm{~kg} \mathrm{ha}^{-1}$ phosphorus rate; though statically at par to that obtained from $46 \mathrm{~kg} \mathrm{P}_{2} \mathrm{O}_{5}$ ha $^{-1}$ under similar transplanting date (figure 3).

From the present result it can be deduced that old seedling age and higher phosphorus rate help to increase the vegetative growth of the plant which has improved assimilate availability for storage and led to an increased average bulb weight that gave an advantage to increase the marketable bulb yield.

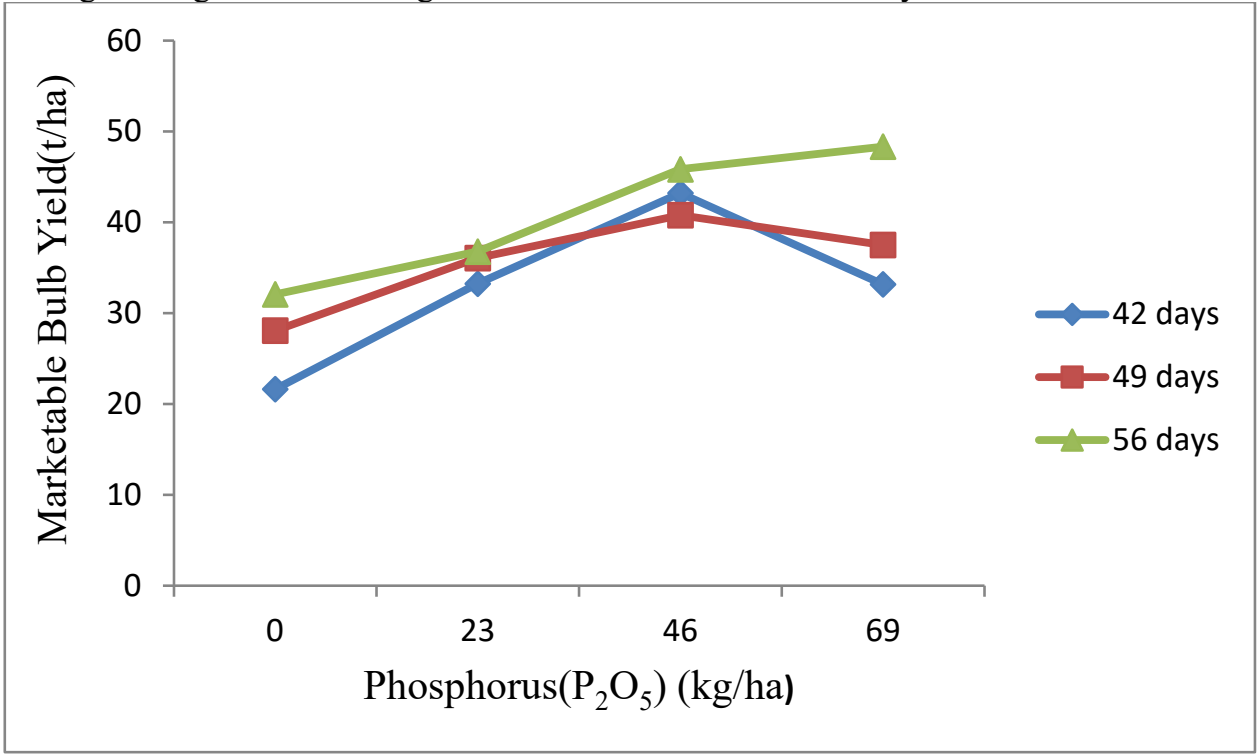

$\operatorname{LSD}(0.05)=4.43$, Significance level $=*$ and CV $(\%)=10.26$

Figure 3: Interaction effects of phosphorus levels and transplanting date on marketable bulb yield $\left(\mathrm{t} \mathrm{ha}^{-1}\right)$ of onion grown at Adami Tulu Jedo Kombolcha Woreda.

\section{Economic Analysis}

The partial budget analysis showed that the highest net benefit of Birr 160567.25 was recorded from the combination of $69 \mathrm{~kg} \mathrm{P}_{2} \mathrm{O}_{5} \mathrm{ha}^{-1}$ and 56 days of transplanting date with marginal rate of $1827 \%$. This was followed by net benefit of Birr 154158.5 from the phosphorus rate of $46 \mathrm{~kg} \mathrm{P}_{2} \mathrm{O}_{5} \mathrm{ha}^{-1}$ and 56 days of transplanting date with the marginal rate of return of $8065 \%$. This means that for every Birr 1.00 invested in $46 \mathrm{~kg} \mathrm{P}_{2} \mathrm{O}_{5}$ ha $^{-1}$ and 56 days of transplanting date, producers can expect to recover the Birr 1.00 and obtain an additional 80.65 Birr. Whereas, the lowest net benefit (Birr $\left.77680 \mathrm{ha}^{-1}\right)$ was recorded from control treatments $\left(0 \mathrm{~kg} \mathrm{P}_{2} \mathrm{O}_{5} \mathrm{ha}^{-1}\right)$ combined with 42 days of transplanting date (Table 5).

The minimum acceptable marginal rate of return (MRR \%) should be between $50 \%$ and 100\% (CIMMYT (1988)). Thus, the current study indicated that marginal rate of return is higher than $100 \%$ (Table 5). Hence, the most economically attractive yield of the onion crop in the study area was that the combinations of $46 \mathrm{~kg} \mathrm{P}_{2} \mathrm{O}_{5}$ ha $^{-}$ ${ }^{1}$ application and 56 days of transplanting date with low cost of production and higher benefits. The yield from the combination of $69 \mathrm{~kg} \mathrm{P}_{2} \mathrm{O}_{5}$ ha $^{-1}$ with 56 days old seedlings still meets the $100 \%$ marginal rate of return threshold value. However, this treatment will not be a viable option because the yield from this combination was statistically 
at par with that obtained from $46 \mathrm{~kg} \mathrm{P}_{2} \mathrm{O}_{5} \mathrm{ha}^{-1}$ and 56 days old age.

Table 4: Economic analysis for phosphorus level and transplanting date experiments of onion at Adami Tulu Jedo Kombolcha Woreda.

\begin{tabular}{|c|c|c|c|c|c|}
\hline $\begin{array}{l}\text { Transplanting } \\
\text { date with } P \text { level }\end{array}$ & $\begin{array}{l}\text { Average yield } \\
\left.(\mathrm{t} \mathrm{ha})^{-1}\right)\end{array}$ & $\begin{array}{l}\text { Adjusted } \\
\text { yield }\left(t \text { ha }^{-1}\right)\end{array}$ & $\begin{array}{l}\text { Gross } \\
\text { benefit } \\
\left(\text { Birr ha }^{-1}\right)\end{array}$ & $\begin{array}{l}\text { Total cost } \\
\text { that } \\
\text { vary }\left(\mathrm{Birr}^{-} \mathrm{ha}^{-}\right. \\
\text {1) }\end{array}$ & $\begin{array}{l}\text { Net benefit } \\
\left(\text { Birr ha }^{-1}\right)\end{array}$ \\
\hline $42 * 23$ & 35.48 & 28.38 & 113520 & 650.75 & $112869.25 \mathrm{~d}$ \\
\hline $49 * 23$ & 39.11 & 31.29 & 125160 & 650.75 & $124509.25 \mathrm{~d}$ \\
\hline $56 * 23$ & 39.54 & 31.63 & 126520 & 650.75 & 125869.25 \\
\hline $42 * 46$ & 45.24 & 36.19 & 144760 & 1001.5 & $143758.5 \mathrm{~d}$ \\
\hline $49 * 46$ & 43.43 & 34.74 & 138960 & 1001.5 & $137958.5 \mathrm{~d}$ \\
\hline $56 * 46$ & 48.49 & 38.79 & 155160 & 1001.5 & 154158.5 \\
\hline $42 * 69$ & 35.01 & 28 & 112000 & 1352.25 & $110647.75 \mathrm{~d}$ \\
\hline $49 * 69$ & 39.52 & 31.62 & 126480 & 1352.25 & $125127.75 \mathrm{~d}$ \\
\hline $56 * 69$ & 50.6 & 40.48 & 161920 & 1352.25 & 160567.75 \\
\hline $42 * 0$ & 24.27 & 19.42 & 77680 & & $77680 \mathrm{~d}$ \\
\hline $49 * 0$ & 31.83 & 25.46 & 101840 & & $101840 \mathrm{~d}$ \\
\hline $56 * 0$ & 35.47 & 25.66 & 102640 & & $102640 \mathrm{~d}$ \\
\hline
\end{tabular}

Note: $d=$ dominance

Table 5: Marginal analysis

\begin{tabular}{|c|c|c|c|c|c|}
\hline $\begin{array}{l}\text { Transplanting date } \\
\text { with P level }\end{array}$ & $\begin{array}{l}\text { Total cost } \\
\text { that vary } \\
\left({\left.\text { Birr } \text { ha }^{-1}\right)}\right.\end{array}$ & $\begin{array}{l}\text { Marginal cost } \\
\left(\text { Birr ha }^{-1}\right)\end{array}$ & $\begin{array}{l}\text { Net benefit } \\
\left(\text { Birr } \mathbf{h a}^{-1}\right)\end{array}$ & $\begin{array}{l}\text { Marginal net } \\
\text { benefit (Birr } \\
\text { ha }^{-1} \text { ) }\end{array}$ & $\begin{array}{l}\text { Marginal rate } \\
\text { of } \\
\text { return (\%) }\end{array}$ \\
\hline $56 * 23$ & 650.75 & - & 125869.25 & - & - \\
\hline $56 * 46$ & 1001.5 & 350.75 & 154158.5 & 28289.25 & 8065 \\
\hline $56 * 69$ & 1352.25 & 350.75 & 160567.75 & 6409.25 & 1827 \\
\hline
\end{tabular}

\section{Conclusions and Recommendations}

The analysis of variance revealed that plant height, leaf length, maturity date, bulb length and average bulb weight were significantly influenced by the main effect of phosphorus levels and transplanting date. However, leaf number per plant, bulb diameter, total biomass yield and unmarketable bulb yield were significantly influenced only by the main effects of different rates of phosphorus fertilizer. From this investigation, significantly taller plant height, leaf number per plant, leaf length and early bulb maturity was obtained at the $46 \mathrm{~kg} \mathrm{ha}^{-1}$ phosphorus rate and transplanting date of 56 days. But, bulb length, average bulb weight and total biomass yield were recorded in the treatments of $69 \mathrm{~kg} \mathrm{ha}^{-1}$ phosphorus rate and 56 days of transplanting date. However, the result of this study indicated that at 46 and $69 \mathrm{~kg} \mathrm{P}_{2} \mathrm{O}_{5}$ ha $^{-1}$ rate there was no significant variation in each parameter.

Hence, the study revealed that, highest yield of marketable and total bulb yield of Bombay Red onion variety were produced at treatment combination of $69 \mathrm{~kg} \mathrm{ha}^{-1}$ phosphorus level with 56 days of transplanting date, but no significant difference was observed in these parameters at $46 \mathrm{~kg} \mathrm{P}_{2} \mathrm{O}_{5} \mathrm{ha}^{-1}$ combinations with same transplanting date. However, the combination of 56 days of transplanting date fertilized with $46 \mathrm{~kg} \mathrm{ha}^{-1}$ phosphorus level also gave statistically comparable yield to the highest value. Therefore, from the present study it can be recommended that, the most economically attractive yield of the onion crop in the study area was obtained by the combinations of $46 \mathrm{~kg} \mathrm{P}_{2} \mathrm{O}_{5} \mathrm{ha}^{-1}$ applications and 56 days of transplanting date with low cost of production and higher benefits. However, to make reliable and acceptable recommendation it is better to repeat this experiment across locations and over seasons.

\section{Acknowledgement}

The authors greatly would like thank you, all of you who are participated this piece of research work from the beginning to the end

\section{Conflict of Interests}

The authors have not declared any conflicts of interests.

\section{References}

Abdissa Yohannes. (2008): Effects of nitrogen and phosphorus rates on growth, yield, quality and storability of onion (Allium cepa L.) on vertisols of Shewa Robit. M.Sc Thesis presented to Haramaya University, Ethiopia Agerie, A., and Afework B. (2013): Habitat preferences, seasonal abundance and diets of rodents in Alage, 
Southern Ethiopia.African Journal of ecology, 52:284-291.

Ahn, P.M. (1993): Tropical soils and fertilizer use.Long man group, UK.

Ali, M. K., Alam M. N., Islam M. S., Islam M. K. and Baree M. A. (2008): Effects of cow dung at different levels of phosphorus on growth, yield and quality seed production of onion. Research Journal of Agriculture and Biological Sciences, 4(1): 86-93.

Aliyu, U., Magaji M.D., A. Singh and S.G. Mohammed. (2007): Growth and yield of onion (Allium cepa L.) as influenced by nitrogen and phosphorus levels. International Journal of Agricultural Research.2: 937-944.

Anisuzzaman, M., Ashrafuzzaman M., Ismail M.R., Uddin M.K. and Rahim M.A. (2009): Planting time and mulching effect on onion development and seed production. African Journal of Biotechnology, 8 (3): 412 416.

Bahadur, M.M., M. Ashrafuzzaman, M.F.Chowdhury and D.N. Mazumder. (2002). Response of chickpea (Cicer arietinum) varieties to different levels of phosphorus. Crop Research Hisar, 23(2):293-299

Bahadur, A., and Singh R. (2005): Influence of seedling age on bulb production of Rabi onion. Ann. Agric.Res. New Series, 26 (1):147-148.

Barzegar M, Rajabi A, Hassandokht MR, Jabbari A. (2008): Chemical composition of different cultivars of onion (Allium cepa L.) produces in Iran. Horticultural Environmental Biotechnology, 49(2): 121-127.

Bijarniya, N. K, M.L. Jat, B.K. Patel and M.L. Bana. (2015): Effect of age of seedling and dates of transplanting on growth, yield andquality of onion (Allium cepa L.) in Rabiat Sardarkrushinagar Dantiwada Agricultural University, North Gujasrat.Journal of Rural and Agricultural Research. 15 (2):38-42.

Brady, N. C. and Weil R. R. (2002): The nature and properties of soils.13th (ed.), Pearson Education Asia. Delhi, India. $960 \mathrm{p}$

Brewster, J.L. (1994): Onions and other vegetable alliums. CAB International, Wallingford, UK. 236p.

CIMMYT (International Maize and wheat improvement center). (1988): From agronomic data to farmer recommendations: An economics training manual. Completely revised edition. Mexico. D.F. pp 19-33.

CSA (Central Statistical Authority). (2010): Report on area and production of private peasants holdings. Vol.4., Addis Ababa, Ethiopia. p.58.

EARO (Ethiopia Agricultural Research Organization). (2004): Directory of released crop varieties and their recommended cultural practices.

Fageria, N. K. (2003): Plant tissue test for determination of optimum concentration and uptake of nitrogen at different growth stages in lowland rice.Commune.Soil Science Plant Anal. 34:259-270.

Fairhurst, T., R. Lefroy, E. Mutert and N. Batijes.(1999): The importance, distribution and causes of phosphorus deficiency as a constraint to crop production in the tropics. Agroforestry Forum 9: 2-8.

Fatma, A., Rizk A.M., Shaheen E.H., Abd El-Samad and Omaima M. Sawan. (2012): Effect of different nitrogen plus phosphorus and sulphur fertilizer levels on growth,yield and quality of onion (Allium cepa L.) Dokki, Egypt. Journal of Applied Sciences Research. 8(7): 3353-3361.

Gambo, B. A., M.D. Magaji, A.I.Yakubu and A.U. Dikko. (2008): Effect of FYM, Nitrogen and weed interference on the growth and yield of onion (Allium cepa L.) at Sokto Rima Valley. Journal of Sustainable Development in Agricultural and Environment, 3(2): 8792.

Hanlet, P.(1990): Taxonomy, Evolution and History. pp.1-26.In:Onions and Allied crops, H.D.Rabinowitch,and J.L.Brewster,eds.,CRC Press Inc,Boca Raton,Florida,USA.

Jawar, A., Abdurrab, Haji M., Muhammad A., Anwar R., Abdul S., Abid K., Junaid K., Abbas J. and Hamid K. (2016): Effect of sowing dates and phosphorus levels on growth and bulb production of onion.Pure and Applied Biology, 5(3): pp 406-417.

Kanton, R.A.L., Abbey L., Hilla R.G. and Tabil N.D. (2002): Influence of transplanting age on bulb yield and yield components of onion. 8:27-37p.

Khodadadi, M. (2012): The effects of planting date and mother bulb size on quantitative and qualitative seed traits of onion red variety.International Journal of Agricultureof CropProduction, 2(4): 324-327.

Kumbhkar, B.R., N.M. Patel and S.G. More. (2016): Effect of age of seedlings on growth, yield and quality of onion (Allium cepa L.) in rabi under North Gujarat condition. Green Farming, 7 (3): 758-759.

Latif, M.A. (2006): Effects of spacing and age of seedling on the growth and yield of summer onion. M.Sc. thesis, Dept. Hort., BAU, Mymensingh. pp 32-33.

Latif, M.A., Choudhury M.S.H., Rahim M.A., Hasan M.K. and Pal B.K. (2010): Effects of spacing and age of seedling on the growth and yield of summer onion.Journal of. Agroforestry and Environment, 3 (2):129-133.

Lemma Dessalegn and Shimeles Aklilu. (2003): Research experiences in onion production. Research report No. 55, EARO, Addis Abeba, Ethiopia. 52 p.

Maurya, K.R, U.K.Singh and R. Singh. (1997): Effect of age of seedling on growth and yield of onion. Journal of Applied Biology, 791(22):55-57.

Muhammad, T., M. Amjad, M. Ali, M. Hanif, M.A.M. Hussein, A. Haseeb and A.Noor.(2017): Seedling age and nitrogen level enhance vegetative growth and yield of onion (Allium cepa L.) at Faisalabad, Pakistan. 
International Journal of Agriculture and Environment Research, 3(2):232 - 239.

Muoneke, C., O.M.Umar and M.D. Magaji. (2003): Growth, yield and keeping quality of onions on as influenced by $\mathrm{N}$ and $\mathrm{P}$ fertilization in a semiarid agro-ecology. Agriculture Environment, 3(2):73-80.

SARC (Sirinka Agricultural Research Center).(2008): List of varieties hand out. Sirinka, Ethiopia.

SAS (Statistical Software) Institute Inc. (2008): SAS/STAT. 9.2.User's guide. Cary, NC: SAS Institute Inc. USA.

Shaheen, A.M, M. Mona, M. Abdel, A.M. Aisha and A.R. Fatma. (2007): Natural and chemical phosphorus fertilizers as affected onion plant growth, bulb yield and its some physical and chemical properties. Australia journal of basic and applied science, Inset publication, 1(4): 519-524.

Singh, J. and N.K. Chaure. (1999): Effect of seedling age and nitrogen levels on growth and yield of onion (Allium cepa L.). Adv. Hort. Forestry, 6: 73-77.

Sultana, MST. (2015): Effect of age of seedlings and number of plants per hill on the growth and yield of onion. M.Sc. Thesis, Dept. Hort., BAU, Dhaka. pp 45-46.

Tyagi AK and Yadav SK. (2007): Effect of growth regulators on growth and yield of onion (Allium cepa L.). Plant Archives, 7(1): 371-372.

Tibebu Simon, Melese Tora, Abrham Shumbulo and Samuel Urkato. (2014): The effect of variety, nitrogen and phosphorous fertilization on growth and bulb yield of onion (Allium cepa L.) at Wolaita, Southern Ethiopia. Journal of Biology, Agriculture and Healthcare, 4:90-92.

Vachhani, M.U. and Z.G. Patel. (1988): Studies on growth and yield of onion as affected by seedling age at transplanting. Progressive horticulture, 20:297-298.

Verma, J.P, S.V.S. Rathore and B.S.Yadav. (1971): Performance of bulb crop of onion as affected by sowing date and age of transplants. Progressive Horticulture, 3(2):29-33. 